\title{
Digital society and society 5.0: Urgent issues for digital social transformation in Vietnam
}

\section{Masyarakat digital dan masyarakat 5.0: Isu mendesak untuk transformasi sosial digital di Vietnam}

\author{
Hoang H. Nguyen ${ }^{1,2^{*}} \&$ Huan V. Tran ${ }^{2}$ \\ ${ }^{1}$ Faculty of Sociology, Russian State Social University \\ ${ }^{2}$ Academy of Politics Region II \\ Address: ${ }^{1}$ Wilhelm Pieck Street, 4, Build.1, Moscow, Russian Federation 129226 \\ 299 Man Thien Street, Hiep Phu Ward, Thu Duc City, Ho Chi Minh City, Vietnam 800000 \\ E-mail: hoangnh@homa2.edu.vn
}

Article History: Received 13 August 2021; Accepted 14 February 2022; Published Online 02 March 2022

\begin{abstract}
Society has been undergoing a complex transformation from a traditional society to a modern, post-modern society with a new state of social history - "digital society", "society 5.0" based on the development of digital technology to help connect things and unprecedentedly change our life. This article uses a qualitative method by collecting, reviewing many Vietnamese and international scientific documents to focus on analyzing three contents: (1) history, concept, and nature of "digital society", "society 5.0", (2) proposing an overall model of a digital society suitable to the reality of Vietnam from the overall "digital society" model of some countries in the Asia-Pacific region and "society 5.0", (3) urgent issues in the process of implementing the goal of building a "digital society" in Vietnam by 2030. These issues discussed are also valuable for reference for countries whose context, culture, and development level are similar to Vietnam's to adapt to digital social transformation. The important result of the study is the proposal of the overall model to build the digital society with four specific criteria: digital economy, digital government, digital culture, and digital society for Vietnamese practice and implications for countries at the same level of development.
\end{abstract}

Keywords: digital social transformation; digital society; society 5.0; Vietnam

\begin{abstract}
Abstrak
Masyarakat telah dan sedang mengalami transformasi yang kompleks yaitu dari masyarakat tradisional menjadi masyarakat modern dan pasca-modern dengan keadaan sejarah sosial baru - "masyarakat digital", "masyarakat 5.0” berdasarkan perkembangan teknologi digital untuk membantu menghubungkan berbagai hal dan perubahan yang belum pernah terjadi sebelumnya dalam hidup kita. Dengan meninjau berbagai dokumen dengan menyaring informasi ilmiah di Vietnam dan internasional yang penting dan relevan dari berbagai sumber, artikel ini berfokus menganalisis tiga hal: (1) sejarah, konsep dan sifat "masyarakat digital", "masyarakat 5.0", (2) mengusulkan keseluruhan model masyarakat digital yang sesuai dengan realitas Vietnam dari keseluruhan model "masyarakat digital” di beberapa negara di kawasan Asia-Pasifik dan "masyarakat 5.0”, (3) isu-isu mendesak dalam proses implementasi tujuan membangun " masyarakat digital” di Vietnam pada tahun 2030. Pembahasan dalam artikel ini juga menjadi nilai masukan bagi negara-negara yang mempunyai latar belakang, kebudayaan, dan tingkat perkembangan yang mirip dengan Vietnam untuk beradaptasi dengan transformasi sosial digital. Hasil utama dari penelitian ini adalah usulan model keseluruhan untuk membangun masyarakat digital dengan empat kriteria khusus: ekonomi digital, pemerintahan digital, budaya digital, dan masyarakat digital untuk diterapkan di Vietnam dan juga implikasinya bagi negara-negara dengan tingkat pembangunan yang sama.
\end{abstract}

Kata kunci: transformasi sosial digital; masyarakat digital; masyarakat 5.0; Vietnam

\section{Introduction}

"Digital society", "society 5.0" are both the reality of life and the new academic concept of about 10 years ago. Searching for the keywords "digital society" or "society 5.0" on Google Scholar, by relevance, selected from 2010 to present, there are 19,400 and 980 search results, respectively, containing these 
terms. Meanwhile, when using the keywords "Vietnam digital society" and "Vietnam society 5.0", no results were found. The research gaps and significance of this article's topic are argued in the following dimensions.

In terms of academic and social awareness, up to now, Vietnam has not had many research works with "digital society", "society 5.0" as the central subject (only three monographs, one of which was translated from that of a foreign author). Topics related to or part of the "digital society" include "digital revolution", "digital transformation", "digital economy", "digital government", "society 5.0", "culture 5.0", "digital environment", "digital human resources" (Think Tank Vinasa 2019), "religious power in a digital society" (Harnadi 2021), building "smart cities" (Aminah 2021), "digital city" (Mossberger et al. 2013), "digital citizenship" (Bennett 2008, Schuler 2001), "digital crime" (Powell et al. 2018), "artificial intelligence", and "5G" network development (Russell \& Norvig 2002, Soldani \& Manzalini 2015, Jackson 2019, Popkova \& Gulzat 2019) have been discussed a lot. However, perceptions are still different, lack of systematicity, not up-to-date, and close to international standards and research results.

The perception of businesses towards digital transformation is not enough. The recent survey results of the Vietnam Chamber of Commerce and Industry are noted that half of the Vietnamese enterprises think that the 4th Industrial Revolution will not be able to affect businesses, while $31,1 \%$ of businesses have yet to do anything to keep up with this Revolution (Nguyen 2019). The annual report "Digital transformation of enterprises in 2021: Barriers and needs of digital transformation" surveyed 1,300 businesses of different sizes and fields showed that only 39,5\% of businesses believe that access to digital transformation knowledge is to "apply" in production and business, to "study" by $26,3 \%$, and to "consult" by 22,1\% (Ministry of Planning and Investment 2021). This report also showed that up to $52,3 \%$ of enterprises said that they had "difficulty in changing business habits and practices", $32,1 \%$ had a "lack of commitment and understanding of the management board enterprises", and 26,6\% had a "lack of commitment and understanding of employees" in the digital transformation process (Ministry of Planning and Investment 2021). The business community is a dynamic, active, and creative subject with new things such as digital technology and digital transformation. However, the reality in Vietnam does not go as expected.

Regarding macro management, in 2019, the Communist Party of Vietnamissued a resolution on proactively adapting to the 4th Industrial Revolution; in 2020, the National Digital Transformation Program (20252030) was approved by the Prime Minister with 3 pillars: digital economy, digital government, and digital society. However, the actual implementation of these political documents and policy documents is quite slow. In January 2021, the Ministry of Planning and Investment officially issued and implemented the Program to support businesses in digital transformation (2021-2025), accompanied by a framework to assess the readiness of small and medium businesses in digital transformation. At the end of 2021, the Ministry of Information and Communications has officially approved the project to determine the index to assess the level of enterprise digital transformation and support digital transformation. Meanwhile, the progress of implementing digital transformation in other pillars such as digital government/ digital locality and digital society of the government is still quite slow, confusing, and difficult.

About 5 years ago, some areas such as Ho Chi Minh City, Quang Ninh, and Binh Duong pioneered the construction and implementation of a sustainable smart city development project. However, the process of carrying out these projects has been confounded by certain difficulties, and they have been unable to make breakthroughs, have not timely updated theories, models, new solutions, or developed systematic scenarios and plans to adapt to the addressed urgent matters and challenges (Nassehi 2021). This is quite consistent with the reports of many international research organizations when assessing Vietnam's digital transformation indicators recently. In ASEAN, indicators on "level of digital connectivity", "digital payment methods", "logistics" based on digital technology, "digital skills" or "policies and regulations" for national digital transformation Vietnam's contribution from 2017 to 2020 is relatively low compared to Indonesia, Thailand, Malaysia, and Philippines (Ministry of Planning and Investment 2021). 
Digital transformation and building the "digital society" are becoming a rule, an inevitable transformation process that governs and changes all aspects of Vietnamese social life profoundly, strongly, and comprehensively. The goal of building Vietnam is clearly defined: "rich people, strong country, democracy, justice, and civilization". Vietnam will "complete the goal of basic industrialization and modernization to become an industrialized country in the direction of modernity" by 2030 , "become a modern industrialized country" by 2045, and become the "digital nation" by 2030 . These make the topic "digital society", "society 5.0" in this article becomes important and necessary. The results of this article supplement and clarify basic awareness, core, and important issues about "digital society", "society 5.0" through interdisciplinary approaches, especially humanities and social sciences (such as philosophy, sociology, culturology, politics, management, etc.) which are still quite lacking. It also helps to raise awareness of the business community and the people - the important subject in the national digital transformation journey. Especially, the article also provides scientific arguments with theoretical value and practical relevance, international standards, as well as Vietnamese identity for state management agencies at all levels from central to local to plan the policies and perfect the institutional system. Since then, it contributes to speeding up the process of national digital transformation, gradually building a digital society with Vietnamese characteristics, and promoting the country's prosperous development in the coming decades.

Hence, the purposes of this article are to: (1) analyze history (formation and development), the most general, essential concept of "digital society", "society 5.0" and its nature, (2) introduce the overall model of "digital society" of some Asia - Pacific countries, the model of "5.0 society" in Japan, thereby contributing to proposing an overall model of a "digital society" in Vietnam by 2030, (3) discuss the important and urgent issues that leaders, managers, and scientists in Vietnamese society need to deal with in the process of building a digital society.

\section{Research Method}

The study was reviewed based on many scientific articles, monographs with keywords "digital society" and "super smart city" in the Google Scholar database from 2000 to the present. This is the time that many researchers have admitted widely, officially the terms "digital society", "society 5.0". These were filtered from international scientific journals and prestigious publishers. Regarding "digital society", we approached the latest report (published in 2020): "Advancing digital societies in Asia Pacific: A wholeof-government approach" in 11 countries with different levels of development in the Asia-Pacific region (including Vietnam) by Global System for Mobile Communications Association (GSMA).

Regarding "society 5.0", we translated and analyzed related content in the "5th Science and Technology Basic Plan (2016-2021)" of Japan's Cabinet Office, where "society 5.0" appeared and its initial features were first mentioned and introduced. This article was also reviewed based on some important contents related to "society 5.0" in "Society 5.0: A people-centric Super-smart Society" book of Hitachi-U Tokyo Laboratory, published in 2020 by Springer. Moreover, the article also used and analyzed a number of research findings, recently published in Vietnam and other relevant political documents and policy documents.

\section{Results and Discussion}

\section{A brief history of digital society and society $\mathbf{5 . 0}$}

Firstly, the digital society has two stages: (1) The first stage: In the mid-1980s, when the personal computer was first introduced to the public and "The World Wide Web" was invented in 1989, social researchers consider this to be the early stage of today's digital era (Lupton 2015). This is also the period of "information and communication technologies" (ICTs), "cyber technologies", and "information society" (Webster 2002, Colin \& Michele 2008); at the same time, we witnessed the development of the World Wide Web at its first level - "Web 1.0" (Lupton 2015). (2) The official stage: The term "digital 
society" is officially used widely in the development process of the Internet at the level of Web 2.0 (equivalent to the second wave of development of the technology), i.e., about the first 10 years of the 21 st century (Think Tank Vinasa 2019). During this period, digitization was used in the academic field and media; at the same time, the expressions "digital society" in terms of expression with many other related terms like "digital people", "digital culture", "digital anthropology", "digital technogeography" were formed and expanded (Lupton 2015). According to WSIS (2003), this time witnessed the World Summit on the Information Society held in Geneva (December 2003), attracting many leaders to attend and discuss the future of building a digital society. From here, affirming the first decade of the twentyfirst century, the "digital society" was officially appeared in the academic field and practice aspect (Sue \& $\operatorname{Jim} 2012)$.

Next is the history of "society 5.0". From the need to solve challenges that have been hindering sustainable development, aiming to balance economic development and solving social issues by a highly integrated system between the virtual and real world, the Japanese Cabinet issued the 5th Science and Technology Basic Plan (2016-2021) on January 22, 2016. Japan aimed to build a "society 5.0" (Cabinet Office n.d, Holroyd 2020, Uehara 2020). From here, it became the first nation to introduce the term, embarked on the construction of "society 5.0" in the world, wished to introduce to the world the first technological achievement of this society, which is expected at the Olympics and Paralympic Games 2020.

\section{The concept and nature of digital society and society $\mathbf{5 . 0}$}

As for the "digital society", at present, although more international studies have been published, there are still many views that are not really agreed on (see Table 1). (1) Firstly, GSMA has given a very significant definition that the press and media in Vietnam often mention. Accordingly, "digital society" refers to a society where people can seamlessly interact with different fields such as their lives, work, entertainment, and communication through digital channels interconnected by smart devices and compatible services. In fact, everyone in the digital society can access and interact with various types of public services provided by the government or private sectors like utilities, transportation, finance, health, and education anytime and anywhere facilitated by digital technology. This is rapidly increasing market segments and new business models - where the lines between products and services are increasingly blurred (GSMA 2016). (2) Secondly, from a social perspective, there is a view that "digital society" is the connection of all aspects in society through the method of digitizing them (Simon 2017). Also in this work, Simon considers "digital society" as an equation that consists of digital media + society, where digital media includes a system of tools that is digitized, connected, and basic infrastructure as the Internet. (3) Thirdly, another view is that "digital society" is the development stage of society based on the achievement of digital technologies (big data and artificial intelligence (AI)), services and utility equipment systems (laptops, computers, smartphones, tablets, etc.) in many different fields such as law, education, social security, and healthcare (Neil 2019).

In Vietnam, there are not many studies that introduce a new and specialized approach to the term "digital society". (1) First of all, some electronic newspapers and documents are mainly translated and approached in the direction of synthesizing concepts that have been studied internationally. According to the Vietnam.net (2020), "digital society" covers all human activities. It relies on the development of digital technology as well as the rapid increase of information and data, which changes every aspect of social organization. In a narrow sense, it includes digital citizenship and culture. In this sense, "digital society", "digital government" and "digital economy" create 3 pillars of the digital country. (2) The next, the book "Question \& Answer on Digital Transformation" by Ho et al. (2020) is perhaps a rare work devoted to emphasizing that a digital society is a society in the digital space, where services and digital platforms will make people's life convenient and easy, provide more jobs, create higher productivity, develop a safer and more humane society, help to balance the economy with life, etc. In particular, the authors believe that society 5.0 is a specific version and expression of digital society. 
Table 1.

Summary of research topics on digital society from 2001 to 2021

\begin{tabular}{|c|c|c|}
\hline 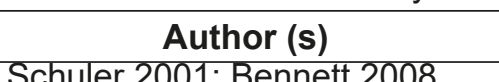 & Topic related to digital society & Features of digital society \\
\hline $\begin{array}{l}\text { Webster 2002; Colin \& Michele } \\
2008\end{array}$ & $\begin{array}{l}\text { information and communication, } \\
\text { technologies (ICTs), cyber } \\
\text { technologies, information society }\end{array}$ & \\
\hline Mossberger et al. 2013 & digital city & \\
\hline Lupton 2015 & digital era & \\
\hline Lupton 2015 & $\begin{array}{l}\text { digital people, digital culture, } \\
\text { digital anthropology, digital } \\
\text { technogeography }\end{array}$ & \\
\hline $\begin{array}{l}\text { Russell \& Norvig 2002; Soldani } \\
\text { \& Manzalini 2015; Popkova \& } \\
\text { Gulzat 2019; Jackson } 2019\end{array}$ & $\begin{array}{l}\text { artificial intelligence/ } 5 \mathrm{G} \text { network } \\
\text { development }\end{array}$ & \\
\hline $\begin{array}{l}\text { Cabinet Office n.d; } \\
\text { Holroyd 2020; Ichiro } 2020\end{array}$ & society 5.0 & \\
\hline GSMA 2016 & digital society & $\begin{array}{l}\text { Digital society - people } \\
\text { interact seamlessly with every } \\
\text { aspect of life. }\end{array}$ \\
\hline Simon 2017 & digital society & $\begin{array}{l}\text { Digital society }=\text { digital } \text { media } \\
+ \text { society }\end{array}$ \\
\hline Powell et al. 2018 & digital crime & \\
\hline Neil 2019 & digital society & $\begin{array}{l}\text { It's the development stage } \\
\text { of society based on the } \\
\text { development of technology, } \\
\text { digital systems of Al and big } \\
\text { data }\end{array}$ \\
\hline Think Tank Vinasa 2019 & $\begin{array}{l}\text { digital revolution, digital } \\
\text { transformation, digital economy, } \\
\text { digital government, society } 5.0 \text {, } \\
\text { culture 5.0, digital environment, } \\
\text { digital human resources }\end{array}$ & \\
\hline $\begin{array}{l}\text { Ministry of Information and } \\
\text { Communications of Vietnam } \\
2020\end{array}$ & digital society & $\begin{array}{l}\text { Digital society mentions } \\
\text { social activities based on the } \\
\text { rapid increase of data and } \\
\text { information }\end{array}$ \\
\hline Ho Tu Bao et al. 2020 & digital transformation & $\begin{array}{l}\text { Digital society - social } \\
\text { activities in a digital space. } \\
\text { Society } 5.0 \text { is a specific } \\
\text { version and expression of } \\
\text { digital society }\end{array}$ \\
\hline $\begin{array}{l}\text { Hitachi-U Tokyo Laboratory } \\
2020\end{array}$ & super-smart society (society 5.0 ) & \\
\hline Harnadi 2021 & religious power in digital society & \\
\hline Aminah 2021 & smart cities & \\
\hline Nassehi 2021 & $\begin{array}{l}\text { matters and challenges in digital } \\
\text { society }\end{array}$ & \\
\hline
\end{tabular}

Source: studied and summarized by the authors

According to these concepts, the article proposes the concept of "digital society" for Vietnamese practice. Accordingly, digital society is a state, a qualitatively new stage of transformation and development of society, in which it is based on the basic platform's technology such as the Internet, Big data, AI, Mobile Technology, etc. that help connect the interaction of all members of society, with everything in all fields 
of social life like the economy, politics, culture, etc. in a digital world. Therefore. It creates positive changes in living standards, humane and modern society, and promotes sustainability. Thus, the essence of "digital society" is the qualitative change in the way of connection and social interaction from the traditional to the interconnectedness of things in various fields and subjects that need to be digitized in social life through a strongly developed and modern technology - digital and digital communication infrastructure system, in line with the world's technology trends.

As for "society 5.0", the content of the initial and most important concepts and perceptions still follows the description in the 5th Basic Plan on Science and Technology (2016-2021) passed by the Japan Cabinet Office. Several points should be noted, including: Firstly, society 5.0 is a social model, a period, and an epoch in history. Accordingly, it is the successor of the previous four types of society, including society 1.0 - hunting and gathering society, society 2.0 - agricultural society, society 3.0 - an industrial society with mechanics, machines, and automation, and society 4.0 - information society with Internet, computers, electronic devices, etc. (see Figure $1 \& 2$ ).

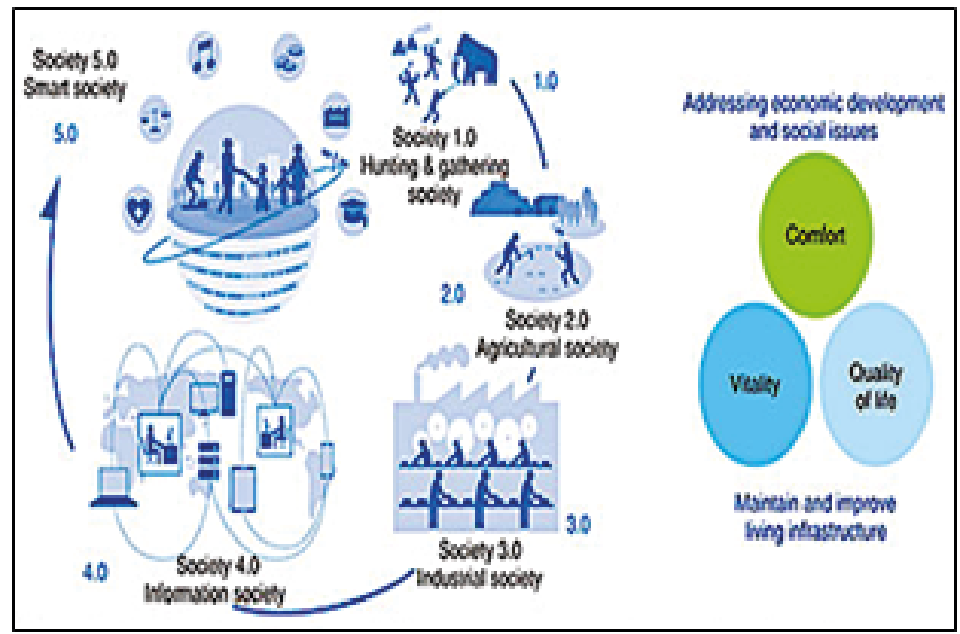

Figure 1.

"Society 5.0" in the course of human social history Source: Cabinet Office (n.d)

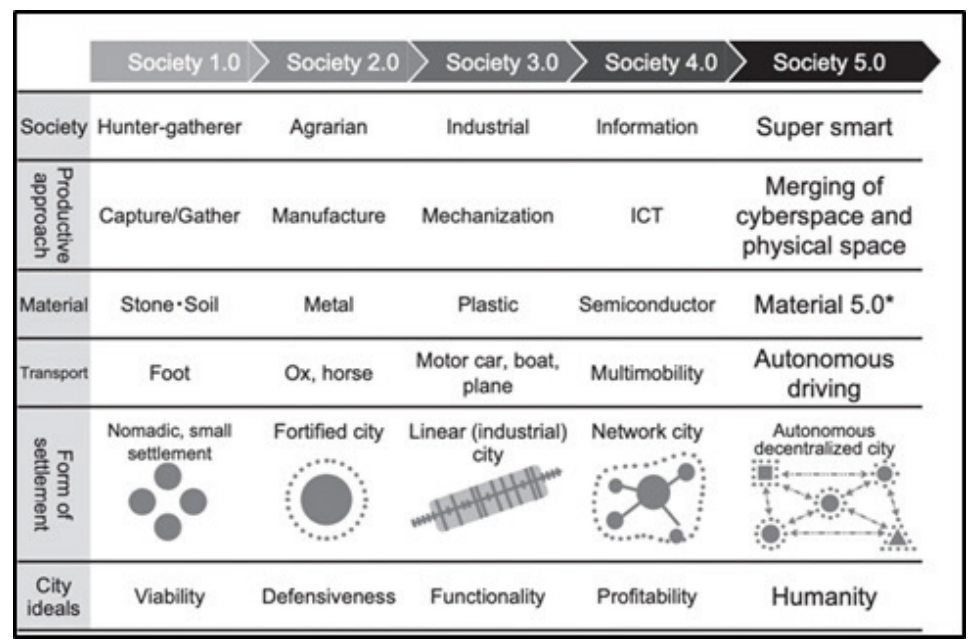

Figure 2.

Contextualizing "Society 5.0"

Source: Hitachi-U Tokyo Laboratory (2020)

Secondly, society 5.0 is a hyper-connected life. It is based on digital platforms and technology derived from the 4th Industrial Revolution (Holroyd 2020). It is creating cyberspace, digital environment, digital society, and digital life in addition to the physical interactive space. It is a solution to promote the great 
challenges towards a comfortable, adequate, and high quality of social life and humane society, humancentered that fulfills the Sustainable Development Goals of the United Nations (Cabinet Office n.d, Holroyd 2020). Everything (including people) in the real (physical) space is connected and digitized through sensors, thereby forming a super-giant data warehouse. This data system will be analyzed, processed by AI and smart, modern digital technologies (computers, robots, autonomous vehicles, smartphones, autonomous traffic lights, etc.) to address the diverse and complex needs and challenges of modern society (see Figure 3, 4 \& 5).

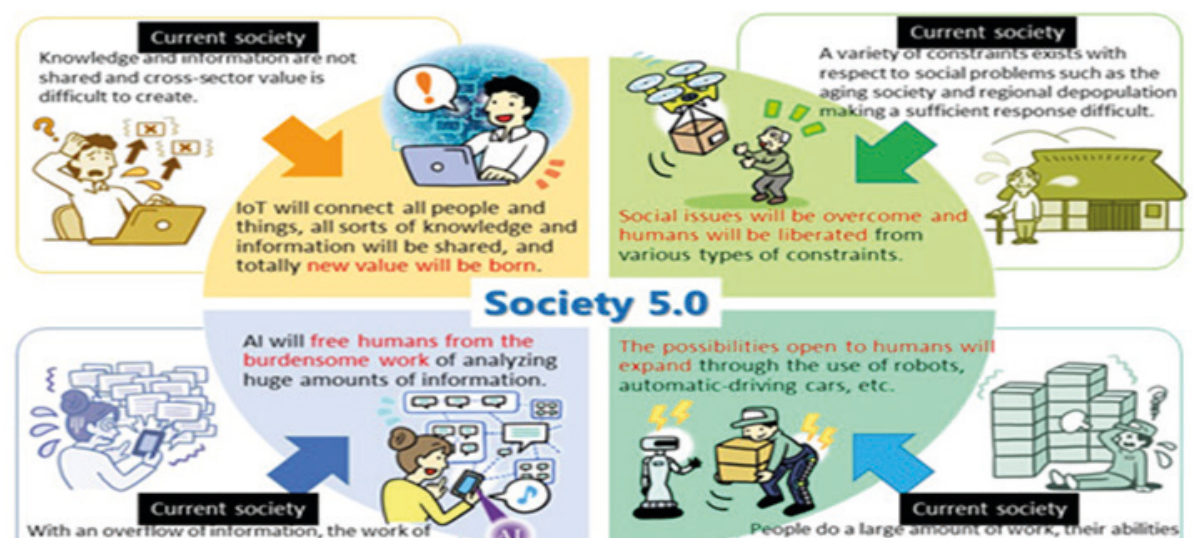

Figure 3.

Society 5.0 creates a hyper-connected society and solves social challenges Source: Cabinet Office (n.d)

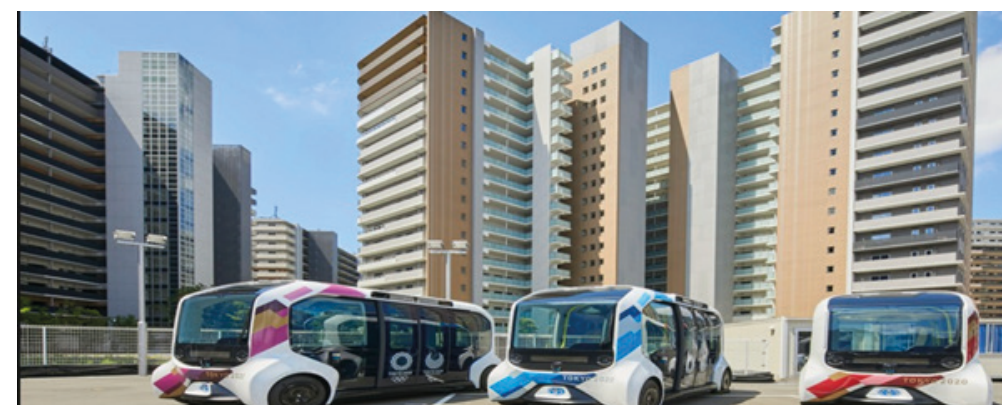

Figure 4.

The e-Palette automatic-driving electric vehicle transports athletes and officials at the Tokyo Olympics Source: Tokyo 2020 (2021)

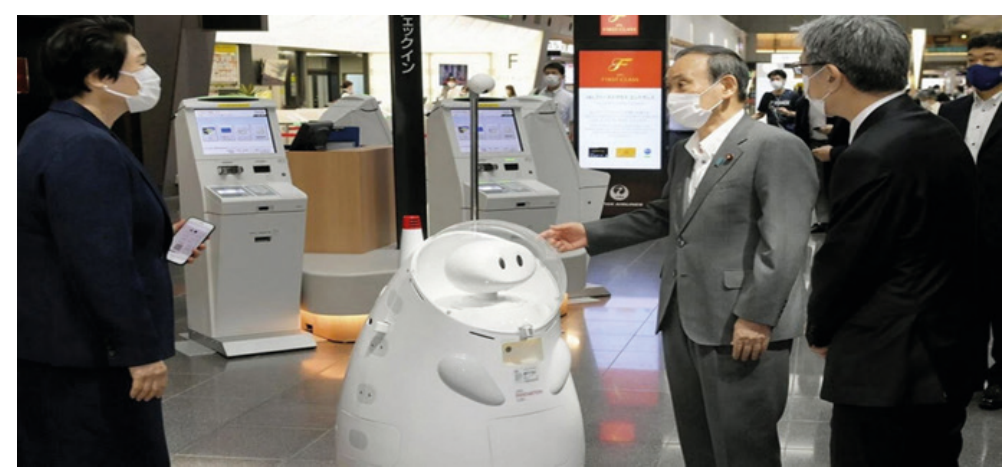

Figure 5.

Japanese Prime Minister Yoshihide Suga next to a robot at Haneda Airport that was put into service of welcoming sports delegations at the Tokyo Olympics

Source: Diep (2021)

Thirdly, the way that society 5.0 works is based on the interconnection of things, big data formation, and the role of data analysis, creating huge information and knowledge to meet the needs of people from all 
walks of life. Society 5.0 is realized by an integrated system between cyberspace (digital/virtual space) and physical/real space (see Figure 6 \& 7).

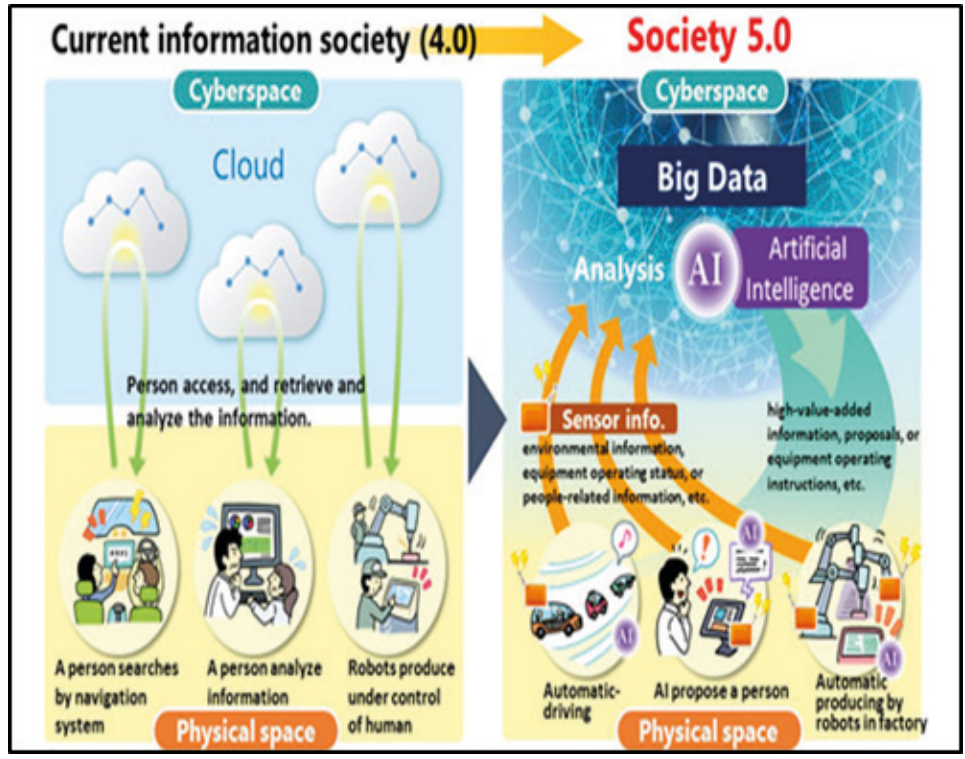

Figure 6.

How society 5.0 works

Source: Cabinet Office (n.d)

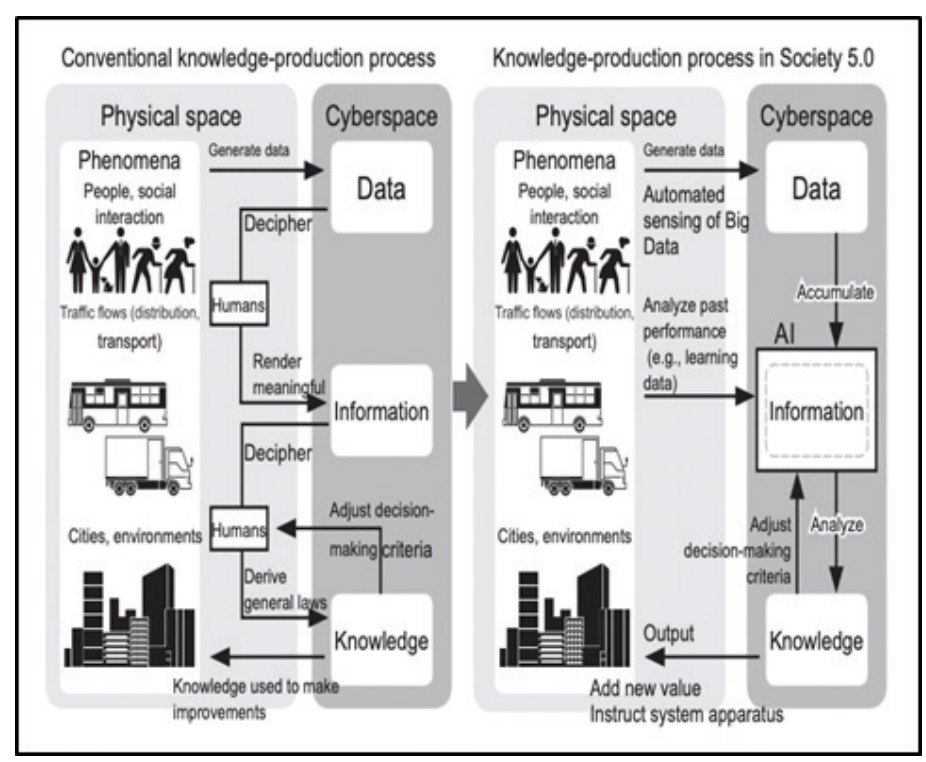

Figure 7.

How society 5.0 works

Source: Hitachi-U Tokyo Laboratory (2020)

In society 4.0, people mainly access cloud services (databases) in cyberspace via the Internet to get information and data and perform analysis according to their needs. However, in society 5.0, the huge data warehouse in digital and virtual space is beyond human ability to analyze to serve their needs. Without the support of advanced technology devices such as AI and modern computers, people will not be able to process the database. In the digital space, AI conducts this big data analysis and the analysis results are fed back to the people in the real space in different ways with countless different needs, bringing new value to society that was impossible before, such as big data that enable self-driving cars to operate on their own in a real environment; searching (accessing) the Internet by voice, online dictionary system or multi-language translation in the network environment; big data that is analyzed to predict natural disasters, socio-economic development, pathologies, and public governance models. Through 
analysis, society 5.0 is proposed and pioneered in Japan (and in this article). The term and model that have appeared recently in the academic and practical literature such as "smart city" is essentially a digital society, a specific, intuitive version, and a vivid model of the digital society model.

\section{Digital society model: Through case studies of some countries in the Asia-Pacific region}

From the special report "Digital society in Asia" of GSMA published in 2016 and 2020 with models and components of digital society in some Asia-Pacific countries, we introduce the content and characteristics of the overall "digital society" model that has been developed by many countries in this region (Table 2). This report has been based on digital social initiatives and/or economic aspirations of 11 countries including Bangladesh, Indonesia, Australia, India, Malaysia, Japan, Thailand, Pakistan, South Korea, Singapore, and Vietnam to establish the overall digital society model.

Table 2.

The overall digital society model in countries in the Asia-Pacific region

\begin{tabular}{|c|c|c|}
\hline Pillar 1: Digital citizenship & Pillar 2: Digital lifestyle & $\begin{array}{l}\text { Pillar 3: } \\
\text { commerce }\end{array}$ \\
\hline $\begin{array}{l}\text { Interactions between government, } \\
\text { citizens, and enterprises through } \\
\text { public services are done by digital } \\
\text { channels. } \\
\text { Expanding online services and } \\
\text { electronic transactions (e-wallet, } \\
\text { tax payment, online voting, online } \\
\text { contract signing, personal information } \\
\text { control, security, online medical } \\
\text { consultation, etc.) }\end{array}$ & $\begin{array}{l}\text { Using smart devices to access } \\
\text { relevant information, play, work, } \\
\text { study, consume, etc. } \\
\text { Social media towards more } \\
\text { eligible experience (virtual reality } \\
\text { - VR, online music, etc.). }\end{array}$ & 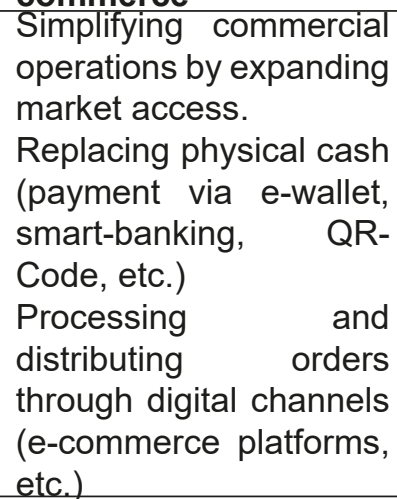 \\
\hline \multicolumn{3}{|c|}{$\begin{array}{l}\text { BACKGROUND AND OPERATION CONDITIONS OF THE THREE COLUMNS: } \\
\text { "Connection (IoT hyperconnection): }\end{array}$} \\
\hline
\end{tabular}
Source: GSMA $(2016,2020)$

The next important contribution of this study is to propose an overall model of digital society with a vision to 2030 in Vietnam (see Table 3). This topic in the academic community has not been mentioned and researched in Vietnam. Vietnam's national digital transformation policies were promulgated in 2020, but macro policymakers have not yet been able to envision, outline, and show specific indicators of the digital society model in the next 10 years. This is a serious gap that needs to be filled. Through studying and reviewing the typical scientific documents from 2001 to 2021 (as shown in Table 1 and Table 2) and based on specific economic, political, cultural, and social contexts, this article proposes the overall model of "digital society in Vietnam" by 2030. The basic theory and approach to propose and build this model are based on the following considerations:

Firstly, politically and legally, we rely on: (1) Resolution No. 52-NQ/TW dated September 27, 2019, of the Politburo of the Communist Party of Vietnam on a number of policies and guidelines to actively participate in the 4th Industrial Revolution, (2) Decision No. 748/QD-TTg dated June 3, 2020, of the Prime Minister approving the "National Digital Transformation Program to 2025, with a vision to 2030".

Secondly, the approach and distinction of the scope of "society" in the "digital society" from the point of view of philosophical - social researchers. In this article, to outline the overall model of Vietnam's "digital society", we research the term "society" at its most general level and its broadest sense. Accordingly, society is all fields and activities in social life, especially in the economic, political, cultural, and social fields. Since then, the overall model of Vietnam's "digital society" in this article has four main pillars: "digital economy", "digital politics", "digital culture", and "digital society". It has 
more than one pillar compared to the overall model of three pillars announced by GSMA. Thirdly, it is based on the generalized world model, especially the "Digital society in Asia" model with three pillars in the GSMA Special Report.

Table 3.

The digital society in Vietnam to 2030

\begin{tabular}{|c|c|c|c|}
\hline $\begin{array}{c}\text { Pillar 1: } \\
\text { The sector of } \\
\text { digital economy }\end{array}$ & $\begin{array}{l}\text { Pillar 2: } \\
\text { The sector of digital } \\
\text { politics }\end{array}$ & $\begin{array}{l}\text { Pillar 3: } \\
\text { The sector of } \\
\text { digital culture }\end{array}$ & $\begin{array}{c}\text { Pillar 4: } \\
\text { The sector of digital } \\
\text { society }\end{array}$ \\
\hline
\end{tabular}

\section{Level 1: The core content of each pillar}

Digital commerce in the performance of official duties of the political system and a digital government

\section{Level 2: Specific content of each pillar}

Digital technology businesses. Innovative product "Made in Vietnam". Product development: digital content, digital communication, digital advertising.

Project of supporting small and medium-sized enterprises in digital transformation. Ecommerce.

\section{Interactions between the} government, citizens, and enterprises through public services are done through digital channels. National data portal (data.gov.vn).

National public service portal (dichvucong.gov. vn).

The digital report, information system, Deploying the latest technology in social media, information, public administrative services on the platform of mobile devices, Al, Big Data Analytics, VR/ $A R$, etc.

Public administration personnel in a virtual environment, etc.
Digital lifestyle

Smart devices to access relevant information, play, study, work, consume, etc. Code of conduct in the digital environment (social networks) Social media towards more convenient experience (virtual reality experience - VR, online music, etc.).
A digital, modern, inclusive, and multilayered welfare and security system
Digital human resource training.

Communication about digital transformation and digital technology. Digital education. Research on social issues from digitalization (Center for answering questions, supporting people affected by digital transformation). Integrating the social security and welfare system on a digital platform (security data, security codes, digitizing health insurance cards, social insurance, telehealth, e-medical record, etc).

\footnotetext{
BACKGROUND AND OPERATION CONDITIONS FOR THE FOUR PILLARS:

Connection (IoT hyperconnection):

Fast, reliable, and constant personal access to the Internet based on:

- 5G Service

- Fiber optic broadband Internet

- Security, Cyber security (GCI).
}

Source: studied, summarized, and proposed by the authors

\section{Important challenges and issues have been faced in the construction of a digital society in Vietnam}

Firstly, it is human resources with the focus on operational capacity in the digital environment, which manifests in three aspects: digital knowledge, digital skills, and response in the digital environment. In which: (1) People as digital citizens must have a certain understanding and insight about digital society and digital transformation (Svalastog et al. 2014, Gajović \& Svalastog 2016), have thoughts 
that support and agree with the building of a digital society and highly adaptive to society 5.0, and know how to practice cultural standards and codes of conduct in the digital space. To realize this, the integration of education, methodical communication in "digital society" and "society 5.0" needs to be carried out regularly and effectively in training institutions by researchers and diverse social classes. We need to use digital space and digital technology besides traditional propaganda of communication. (2) People as digital human resources: "Digital society", "society 5.0" provides new jobs, increased work productivity, and first-class convenience. However, a large traditional workforce will be displaced by AI and technology (Fonseca 2018, Ho et al. 2020), thereby, we need policy and capacity to adapt to it (Svalastog et al. 2017). The AI development strategy in Vietnam and the developing countries as a whole should take into account social issues as much as possible, avoiding the conflict between "humans" and "robots" in the future in the fields of science and technology, for example, terrorist groups use AI and digital technology against the government, against humanity, causing political instability in society. In addition, the problem of "robot ethics" or the appearance of more and more AI and robotic systems may cause many jobs for people to be lost and replaced, resulting in many new professions; Unskilled labor is replaced by AI. (3) People as owners, administrators and entrepreneurs in digital businesses: Digital transformation to form a new type of economy - digital economy, sharing economy, business in the digital environment is becoming a trend that is difficult to reverse. Therefore, as Vietnam's trade space with the world expands through a new generation of free agreements, entrepreneurs, owners, and business administrators need to be aware of it early and act accordingly to adapt to the digital society and business model with high digitization requirements. (4) People as a team of leaders and managers to implement the digital civil service and digital government: The thinking and capacity of the team of leaders, managers, public employees, and civil servants need to know, understand thoroughly, motivate, and take the lead for businesses so that society can receive special attention. The development of a project, a roadmap for training, fostering, and raising awareness for this team of the national digitization process also needs to be done soon.

Secondly, it is necessary to study and boldly form a "sandbox" to build a "digital society" and "society 5.0". From a legal perspective, Chu Thi Hoa (2020) said that "sandbox" is a form of creating a favorable operating environment with its own legal and policy framework (possibly disruptive, different from the current legal framework) to conduct testing and scaling up new and effective models. Although Vietnam has gradually improved its institutional system to build a digital society, it still needs a new and breakthrough institutional framework such as: (1) Building a "sandbox" to nurture, lead, and promote the process of digital transformation and the formation of a "digital society", as well as overcoming the drawbacks in this process in Vietnam. In particular, paying attention to data "sandboxes" (data policy, big data law), AI "sandbox" (AI production, operation, and ethical issues, etc.), 5G network development, security "sandbox" privacy, and user safety in the digital space, especially in sensitive areas of finance - banking, justice, insurance, healthcare, etc. (Soldani \& Manzalini 2015, Noda et al. 2017, Popkova \& Gulzat 2019). (2) Building a "sandbox" to ensure the participation of non-state and state entities in the process of digital government (Collin 2015), and (3) Building a "sandbox" on the overall model of "digital society", "society 5.0" in Vietnam. If we thoroughly examine Vietnam's National Digital Transformation Program between 2025 and 2030, we will find that this information is quite poor and even embarrassing.

Thirdly, "digital society", "society 5.0" brings new opportunities but also poses a series of challenges of political life in the context of "digital politics". It includes the determination of the management method of "digital society", "society 5.0", the principle of "flexible governance", etc. in Vietnam. It also leads to some questions such as (1) where will the digitization of activities in the political system begin and to what extent, (2) how is digital government different from e-government, (3) how does it operate, and (4) how is its construction going? In particular, the "digital society" is associated with ensuring human rights and citizens' rights. In addition, it questions how the nature of the Vietnamese political regime operated according to the model of "digital politics" will be like, while the "digital society" will be the same. With the background of technology and digital communication, on the one hand, it has significantly changed many core values of freedom, justice, democracy, social solidarity, social welfare, 
etc. but also contains risks for users such as being used to incite violence, riots, discrimination, ethnic enemies, deep division of religion and gender.

Finally, research deeply identify a series of urgent issues about social life brought about by the digital society in order to have appropriate behavioral policies. First, "Digital society" brings unprecedented comfortable, new, and modern life but also threatens the basic rights and safety of people between the real space and the digital space. Privacy is easily violated; even personal information becomes a commodity that is widely traded and bought online (Powell et al. 2018). Second, "Digital society" creates new qualitative, very rapid, and profound changes in the value system of society, culture, and social morality. It results in new trends that are both mixed and contradictory even conflict in today's social relations compared to the traditional society. Vietnam is a country with a long-standing agricultural civilization, "having many thousands of years of experience", and farming is the basic profession of the entire country, which summarizes the tradition, morality, and culture imbued with the identity of farmers, agriculture, and rural areas (Luong Duc Thiep 2017). However, the digital society is a comprehensive and substantive change in all areas of social life, including the field of "digital culture". It creates conditions to enjoy advanced, unprecedented, and new cultural values through modern technology. It also changes the social value system and standards in the digital environment with bad habits, bad hobbies, and deterioration of morality and lifestyle. It emerged as a new social phenomenon. "Despite being less active, people today always feel busy, lack of time, etc. Urban lifestyle makes people always in a hurry, eat fast, drink fast, talk fast, go fast, communicate fast, everything is fast" (Think Tank Vinasa 2019). People also worry that AI can replace humans or have a negative impact in the field of love, sex, family, and marriage.

Third, "Digital society" changes social communication and interaction, even the living environment in virtual - real and real - digital space. However, virtual spaces and digital societies sometimes make the interaction and social solidarity of family, group, and community members "looser" than before, even at the risk of breaking up. People feel more "lonely", more tired, stuck, and stressed even though the digital living space, connection, and communication are more convenient and open than ever. On the other hand, the convenience and ease of setting up and interacting in the virtual space have made some people, especially the young, tend to "delusion" about themselves and nonstandard behavior. They also tend to forget, leave, or "trivialize" the noble values of national traditions and morality in the intimacy and real life of the family with children, parents, spouses, friends, and responsibility to the country.

Fourth, "Digital society" forces us to define and even re-perceive the central parts constituting the concept of "social development management" which was officially recognized for the first time by the Communist Party of Vietnam in the Document of the 12th National Party Congress (2016) and the Document of the 13th National Party Congress (2021) in a new perspective, that is: The development of management space is no longer limited to the real society or the existing physical world, but the digital space, a digital society connected to all things crosses borders in the traditional sense to quickly open up a large inter-regional, continental, global, and hyper-connected space. Social development management tools and methods need to consider the participation of modern digital technology from social media and social networks in the form of a non-face-to-face (anonymous) online (live streaming) system. The object of management appears as a "human-machine" that will change the quality of longstanding public service relationships. Nowadays, there are many cases as AI workforce or robot-human resources. AIs in various countries are granted citizenship, participate in politics, run for positions in the public administration, join and contribute in many professional fields such as medicine, mediatelevision, transportation, etc. Therefore, the concept (classical science) in sociology (in particular) that "society" with human individuals is only human society or a group of people "by flesh and blood" needs to be recognized and complemented. 


\section{Conclusion}

In particular, the article has contributed scientifically when building the basis and proposing and outlining an overall model of "digital society in Vietnam by 2030" (which has not been mentioned in any local studies). While in the latest research of GSMA, the overall model of "digital society" consists of 3 main pillars: "digital citizenship", "digital lifestyle", and "digital commerce", this study proposes a model that includes 4 main pillars to be applied in Vietnam. Based on a number of political-legal documents of Vietnam, social science knowledge (especially the philosophical - sociological approach), the premise of some practical models in the research results of GSMA, and the principle of systematic, inclusive, and general approach, the article proposes an overall model of "digital society in Vietnam" by 2030 that include four pillars: "digital economy", "digital politics", "digital culture", and "digital society".

Digital social transformation in Vietnam in the next 10 years is a comprehensive transformation process in the four most important aspects such as economic, political, cultural, and social aspects of Vietnamese social life based on the foundation of digital technology, an achievement of the 4th Industrial Revolution. Although it is called building a "digital society", the social field or social aspect should not be understood in a narrow sense. It is the general, systematic, and inclusive approach to social life with the 4 main operational aspects mentioned above. In each pillar, this study focuses on pointing out the most important and other important contents as goals and manifestations that need to be realized in the journey towards building a "digital society" in Vietnam. This is extremely necessary because it helps leaders, managers, and social researchers understand the overall model that is quite clear and detailed with the criteria that have been gradually outlined and initiated. This is also an indicator to evaluate and monitor the entire implementation process of Vietnam's National Digital Transformation Project as well as help identify the roadmap and results of building the "digital society" or digital social life. In fact, there is a big gap both in macro policymaking and research on this topic in Vietnam in particular.

Moreover, this study also pointed out that significant groupings of problems are also challenges and obstacles that need special attention in order to have solutions to respond, solve, and study thoroughly in the process of implementing the National Digital Transformation Program as well as towards building a "digital society" with a vision to 2030 in Vietnam. The initial comments and discussions of this article will hopefully suggest some ideas for future research on this issue.

\section{References}

Aminah S (2021) The public rights to the sidewalk in a smart city framework: The case study of Surabaya. Masyarakat, Kebudayaan dan Politik 34 (2):221-234.

Bennett WL (2008) Changing Citizenship in the Digital Age. Civic Life Online: Learning How Digital Media Can Engage Youth. Foundation Series on Digital Media and Learning. Cambridge: The MIT Press. 1-24. https://doi.org/10.1162/dmal.9780262524827.001.

Cabinet Office (n.d) Society 5.0. [Accessed 25 July 2021]. https://www8.cao.go.jp/cstp/english/ society5_0/index.html.

Chu TH (2020) Sandbox - cơ chế thử nghiệm áp dụng trong phạm vi hạn chế - kinh nghiệm quốc tế và một số gợi ý cho Việt Nam. Nghien Cuu Lapphap, 07 January. [Accessed 20 July 2021]. http:// lapphap.vn/Pages/tintuc/tinchitiet.aspx?tintucid=210382.

Colin L \& Michele K (2008) Digital Literacies. New York: Peter Lang Publishing.

Collin P (2015) Young Citizens and Political Participation in a Digital Society: Addressing the Democratic Disconnect. New York: Springer.

Communist Party of Vietnam (2016) Document of the 17th National Congress of Delegates. Hanoi: The Truth National Political Publishing House.

Communist Party of Vietnam (2021) Document of the 13th National Congress of Delegates. Hanoi: The Truth National Political Publishing House.

DiepA(2021) Japan shows off tech power at Tokyo Olympics. VN Express, 23 July. [Accessed 28 July 2021]. https://vnexpress.net/nhat-ban-pho-dien-suc-manh-cong-nghe-qua-olympic-tokyo-4329335.html. 
Fonseca L (2018) Industry 4.0 and the digital society: Concepts, dimensions and envisioned benefits. Proceedings of the International Conference on Business Excellence 12 (1):386-397. https://doi. org/10.2478/picbe-2018-0034.

Gajović S \& Svalastog AL (2016) When communicating health-related knowledge, beware of the black holes of the knowledge landscapes geography. Croatian Medical Journal 57 (5):504-509. https:// doi.org/10.3325/cmj.2016.57.504.

GSMA (2016) Advancing Digital Societies in Asia. United Kingdom: GSMA Head Office.

GSMA (2020) Advancing Digital Societies in Asia Pacific: A Whole of Government Approach. United Kingdom: GSMA Head Office.

Harnadi D, Siahaan H, \& Hilmy M (2021) Pesantren and the preservation of traditional religious authority in the digital age. Masyarakat, Kebudayaan dan Politik 34 (3):272-280. http://doi.org/10.20473/ mkp.V34I32021.272-280.

Ho TB, Nguyen HD, \& Nguyen NQ (2020) Q\&A about Digital Transformation. Hanoi: Information and Communication Publishing House.

Holroyd C (2020) Technological innovation and building a 'super smart' society: Japan's vision of society 5.0. Journal of Asian Public Policy, 1-14. https://doi.org/10.1080/17516234.2020.1749340.

Hitachi-U Tokyo Laboratory (2020) Society 5.0: A People-centric Super-smart Society. Singapore: Springer Open.

Jackson PC (2019) Introduction to Artificial Intelligence. New York: Courier Dover Publications.

Luong Duc Thiep (2017) Society of Vietnam: From Prehistory to Modern Times. Hanoi: Knowledge Publishing House.

Lupton D (2015) Digital Sociology. London: Routledge.

Ministry of Information and Communications of Vietnam (2020) Experience of building a digital society. [Accessed 17 July 2021]. https://aita.gov.vn/kinh-nghiem-xay-dung-xa-hoi-so.

Ministry of Planning and Investment (2021) Annual report on digital transformation highlights barriers to overcome. [Accessed 20 July 2021]. https://www.mpi.gov.vn/Pages/tinbai. aspx?idTin $=52749 \&$ idcm $=131$.

Mossberger K, Tolbert C, \& Franko W (2013) Digital Cities: The Internet and the Geography of Opportunity. New York: Oxford University Press.

Nassehi A (2021) Talk on a Series of Topics: "Digital society": "What Problems Does Digitalization Solve? Hanoi: Goethe Institut.

Neil S (2019) What is Digital Sociology? United Kingdom: Politics Press.

Nguyen Q (2019) Only 50\% of Vietnamese enterprises are aware of the impact of Industry 4.0. [Accessed 17 July 2021]. https://vov.vn/kinh-te/moi-chi-50-doanh-nghiep-viet-nhan-thuc-ve-tac-dong- cuacmen-40-896800.vov.

Noda K, Wada Y, Saiki S, Nakamura M, \& Yasuda K (2017) Delivering personalized information to individuals in super smart society. International Conference on Digital Human Modeling and Applications in Health, Safety, Ergonomics and Risk Management, July 9-14. Canada: HCI International. 336-347.

Popkova EG \& Gulzat K (2019) Technological Revolution in the 21st Century: Digital Society vs. Artificial Intelligence. In: Popkova E, Sergi B. (eds) The 21st Century from the Positions of Modern Science: Intellectual, Digital and Innovative Aspects. ISC 2019. Lecture Notes in Networks and Systems, 91. New York: Springer. https://doi.org/10.1007/978-3-030-32015-7_38.

Powell A, Stratton G, \& Cameron R (2018) Digital Criminology: Crime and Justice in Digital Society. London: Routledge.

Russell S \& Norvig P (2002) Artificial Intelligence: A Modern Approach, Global Edition $4^{\text {th }}$. London: Pearson Education.

Schuler D (2002) Digital Cities and Digital Citizens. In: Tanabe M, van den Besselaar P, Ishida T (eds). Digital Cities II: Computational and Sociological Approaches. Digital Cities 2001. Lecture Notes in Computer Science. Berlin: Springer. https://doi.org/10.1007/3-540-45636-8_6.

Simon L (2017) Digital Media \& Society. Singapore: SAGE.

Soldani D \& Manzalini A (2015) Horizon 2020 and beyond: On the 5G operating system for a true digital society. IEEE Vehicular Technology Magazine 10 (1):32-42. 
Sue W \& Jim R (2012) Social Work in a Digital Society. London: SAGE.

Svalastog AL, Allgaier J, Martinelli L, \& Gajović SD (2014) Confusion, and impasses: Could a public dialogue within knowledge landscapes contribute to better communication and understanding of innovative knowledge? Croatian Medical Journal 55 (1):54-60. https://doi.org/10.3325/ cmj.2014.55.54.

Svalastog AL, Donev D, Kristoffersen NJ, \& Gajović S (2017) Concepts and definitions of health and health-related values in the knowledge landscapes of the digital society. Croatian Medical Journal 58 (6):431-435. https://doi.org/10.3325/cmj.2017.58.431.

Think Tank Vinasa (2019) Vietnam in the Digital Transformation Era. Hanoi: World Publishing House.

Tokyo 2020 (2021) Photos. [Accessed 28 July 2021]. https:/olympics.com/tokyo-2020/en/news/photos/ galleries/athlete-village.

Uehara I (2020) Toward the realization of smart regional societies, "to be the social ICT pioneer". [Accessed 20 July 2021]. https://ntt-review.jp/archive/ntttechnical.php?contents=ntr202104fa2_s. html.

Vietnam.net (2020) What is digital transformation in society? Vietnam.net, 18 October. [Accessed 19 July 2021]. https:/vietnamnet.vn/vn/cong-nghe/chuyen-doi-so-trong-xa-hoi-la-gi-681839.html.

Webster F (2002) Theories of the Information Society. London: Routledge.

WSIS (2003) Declaration of Principles, Building the Information Society: A Global Challenge in the New Millennium. Document WSIS-03/GENEVA/DOC/4-E. [Accessed 15 July 2021]. http:// www.itu.int/dms_pub/itu-s/md/03/wsis/doc/S03-WSIS-DOC-0004!!MSW-E.doc. 